\title{
The Effectiveness of Islamic MicrofinanceDistribution on Microbusiness Owner's Poverty Alleviation (Case Study: BMT Bina Masyarakat Purworejo)
}

\author{
${ }^{1}$ A GENG PRASETYO, 2J AENAL EFFENDI, ${ }^{3}$ TITA NURSYAM SIAH \\ Department of Sharia Economics, IPB ${ }^{1,2,3}$ \\ e-mail: prasetyoageng68@gmail.com ${ }^{1}$, \\ jaenfendi@gmail.com², titanursyamsiah@ apps.ipb.ac.id ${ }^{3}$
}

\section{ABSTRACT.}

The objective of the study is to analyze the effectiveness of I slamic microfinance distribution and its impact on microbusiness owners' poverty alleviation in Purworejo. This study used descriptive analysis method that is L ikert scaleand ordinary least square method $(0 \mathrm{LS})$ to analyze the influence of Islamic M icrofinance Institution's financing to microbusiness performance. The impact on the poverty alleviation is indicated by the change of microbusiness owners' income. The results indicate that I slamic microfinancing is considered to be effective in several aspects, they are proposal aspect, disbursement aspect, utilization aspect, and pay-back aspect of financing. In addition, Islamic microfinance has a positive impact on microbusiness performance and poverty all eviation.

$\mathrm{K}$ eywords: effectiveness, I slamic M icrofinance Institution (I slamic M FI), O LS, paired sample ttest, poverty

\section{ABSTRAK}

Tujuan dari penelitian ini adalah untuk menganalisis efektivitas distribusi keuangan mikro syariah dan dampaknya terhadap pengentasan kemiskinan pemilik usaha mikro di Purworejo. Penelitian ini menggunakan metode analisis deskriptif yaitu Skala Likert dan metode O rdinary Least Square (OLS) untuk menganalisis pengaruh pembiayaan Lembaga Keuangan M ikro Islam terhadap kinerja bisnis mikro. D ampak pada pengentasan kemiskinan ditunjukkan oleh perubahan pendapatan pemilik usaha mikro. Hasil penelitian menunjukkan bahwa pembiayaan mikro syariah dianggap efektif dalam beberapa aspek, yaitu 
aspek proposal, aspek pengeluaran, aspek pemanfaatan, dan aspek pengembalian pembiayaan. Selain itu, keuangan mikro Islam memiliki dampak positif pada kinerja bisnis mikro dan pengentasan kemiskinan.

$\mathrm{K}$ ata kunci: efektivitas, Islamic M icrofinance Institution (Islamic M FI), O LS, paired sample t-test, kemiskinan

\section{INTRODUCTION}

Indonesia's poverty level is considered high. However, the number has experienced a decrease for these past years. The poverty in Indonesia is concentrated in the rural village. As many as 16.31 million people who live under the poverty line were located in the rural area, while the other 10.27 million people were located in the urban area. ${ }^{1}$ This was happened because of the insufficient ability of the people who live in the rural area to afford their basic necessities (food, home, and clothes) due to their low income. ${ }^{2}$ It is an important issue to find a solution regarding poverty alleviation in Indonesia. One of the attempts in poverty alleviation is the development of microenterprises/microbusiness sector. In fact, microbusiness has an important role in stirring a country's economy. ${ }^{3}$ Besides that, microbusiness also holds many other important roles.

First, microbusiness contribution to Gross Domestic Product (GDP) in Indonesia is considered high. In 2017, the business sector's contribution to GDP increased by 0.16 percent. From the total contribution, Micro, Small and Medium Enterprises (MSM Es) has a higher share than the bigsized business. Microbusiness dominated the share of MSM Es by 36.82 percent of the total business sector and claimed 4727989 billion rupiahs as its contribution to the GDP in 2017. This data is demonstrated in table 1.

Tabel 1 B usiness Sector's Contribution to the GD P (2016-2017)

\begin{tabular}{lllll}
\hline \multirow{2}{*}{ Indicator } & $\mathbf{2 0 1 6}$ & & $\mathbf{2 0 1 7}$ & \\
\cline { 2 - 5 } & $\begin{array}{l}\text { Share } \\
\text { (percent) }\end{array}$ & $\begin{array}{l}\text { Nominal } \\
\text { (billion) }\end{array}$ & $\begin{array}{l}\text { Share } \\
\text { (percent) }\end{array}$ & $\begin{array}{l}\text { Nominal } \\
\text { (billion) }\end{array}$ \\
\hline Total MSMEs & 59.84 & 7009283 & 60.00 & 7704636 \\
Microbusiness & 36.65 & 4292288 & 36.82 & 4727989 \\
Small business & 9.63 & 1128057 & 9.61 & 1234211 \\
Medium business & 13.57 & 1588938 & 13.57 & 1742436 \\
Total big-sized business & 40.16 & 4703168 & 40.00 & 5136223 \\
\hline
\end{tabular}


Second, microbusiness had an ability to absorb many labors in Indonesia. The share of labor absorption by the M SM Es sector was 97.02 percent or 116673416 people in 2017. From this total share, microbusiness claimed the biggest share by absorbing 107232992 labors in 2017 and experienced an increase compared to the previous year. The business sector's contribution in labor absorption can be seen in table 2 .

Microbusiness growth is also indicated by the increase of its business unit number. Microbusiness sector becomes a dominating sector in Indonesia. The number of micro business unit increased by 1243322 in 2017. The information on microbusiness growth according to the number of its business unit can be seen in table 3 .

Table 2 B usiness sector's contribution to labor absorption (2016-2017)

\begin{tabular}{lllll}
\hline \multirow{2}{*}{ Indicator } & $\mathbf{2 0 1 6}$ & \multicolumn{2017}{l}{} \\
\cline { 2 - 5 } & $\begin{array}{l}\text { Share } \\
\text { (percent) }\end{array}$ & $\begin{array}{l}\text { Number } \\
\text { (labor) }\end{array}$ & $\begin{array}{l}\text { Share } \\
\text { (percent) }\end{array}$ & $\begin{array}{l}\text { Number } \\
\text { (labor) }\end{array}$ \\
\hline Total MSMEs & 97.04 & 112828610 & 97.02 & 116673416 \\
Microbusiness & 89.31 & 103839015 & 86.17 & 107232992 \\
Small business & 4.65 & 5402073 & 4.74 & 5704321 \\
Medium business & 3.09 & 3582522 & 3.11 & 3736103 \\
Total big-sized business & 2.96 & 3444746 & 2.98 & 3586769 \\
\hline
\end{tabular}

Source: Kemenkop 2017 (processed)

Table 3 The number of business sector unit (2016-2017)

\begin{tabular}{lllll}
\hline \multirow{2}{*}{ Indicator } & $\mathbf{2 0 1 6}$ & & $\mathbf{2 0 1 7}$ & \\
\cline { 2 - 5 } & $\begin{array}{l}\text { Share } \\
\text { (percent) }\end{array}$ & $\begin{array}{l}\text { Number } \\
\text { (unit) }\end{array}$ & $\begin{array}{l}\text { Share } \\
\text { (percent) }\end{array}$ & $\begin{array}{l}\text { Number } \\
\text { (unit) }\end{array}$ \\
\hline Total MSMEs & 99.99 & 61651177 & 99.99 & 62922617 \\
Microbusiness & 98.71 & 60863578 & 98.70 & 62106900 \\
Small business & 1.19 & 731047 & 1.20 & 757090 \\
Medium business & 0.09 & 56551 & 0.09 & 58627 \\
Total big-sized companies & 0.01 & 5371 & 0.01 & 5460 \\
\hline
\end{tabular}

Source: Kemenkop 2017 (processed)

Microbusiness owners cope with many obstacles in developing their business. Several of the obstacles are undeveloped business marketing, limitation of production technique, rivalry with the similar other businesses, difficulty in obtaining raw materials, and the limited access to funding 
instruments. ${ }^{4}$ M eanwhile, limited access to funding instrument is considered as the biggest obstacle for microbusiness owners. The limited access to the funding instrument leads to an undeveloped business, limited investment and many other aspects. ${ }^{5}$

The regulation of Bank Indonesia number 15/12/PBI/2013 as the revised version of number $14 / 22 / \mathrm{PBI} / 2012$, stated that commercial bank is obligated to allocate credit to microbusiness for at least 20 percent of the total credit. ${ }^{6}$ However, in fact, microbusiness is considered to be unbankable business unit since it has a considerably small capital. The small capital tends to consume more transaction cost for the bigger business unit. ${ }^{7}$

Microfinance institution helps the funding access to the microbusiness with the simpler and easier qualifications compared to the commercial banking institution. ${ }^{8}$ This was indicated by the requirements that particularly do not burden the business owners. According to the study that was done in Nigeria, microfinance had an important role in poverty alleviation and growing the spirit of entrepreneurship in both urban and rural people. ${ }^{9}$ M icrofinance institution's customers are the low-income business owners that autonomously manage their business, regardless of their location (urban or rural area). ${ }^{10}$

Islamic Microfinance Institutions (Islamic M FIs) help on opening the funding (or financing) access to the low-income microbusiness owners that are not considered as bankable. ${ }^{11}$ Microbusiness owners are allowed to access islamic financing in four ways. First, obtaining islamic financing through an islamic commercial bank. Second, obtaining islamic financing through Baitul Maal wat Tamwil, or islamic cooperative. Third, obtaining islamic financing through Badan Amil Zakat Nasional (BAZNAS) or Lembaga Amil Zakat Nasional (LAZ). Fourth, obtaining islamic financing through a government program, such as Kredit Usaha Rakyat (KUR) -citizenry business credit-, etc. ${ }^{12}$

'The Triangle of Microfinance' concept has a capacity to be stated as a performance indicator for the financial institutions that provide islamic financing. The concept covers three indicators in regards to the performance of the financial institution, they are financing's sustainability, outreach, and impact. ${ }^{13}$ Meanwhile, the indicator of 'impact' is deemed as the indicator that had the most tend to be directly and clearly experienced by business owners.

Islamic MFls has a capability in providing solutions to the financing 
access problem that is faced by microbusiness in a rural area. The multiplier effect that is emerged from the financing has an ability to eventually alleviate the poverty by increasing the business owners' income. ${ }^{14}$ Islamic M Fls had a role in poverty alleviation in three different area's typologies (coastal area, lowland, and plateau) of Pasuruan, East Java. ${ }^{15}$ Islamic M FIs' funding was deemed to be effective for poverty alleviation by increasing most of the customer's income after joining Islamic M Fl's financing program. ${ }^{15}$ Thus, this study is important to be conducted to assess the effectiveness of Islamic M FI in Purworejo.

\section{METHODOLOGY}

This study used qualitative and quantitative data. The qualitative data that were obtained were used to support the results of the study that was particularly done by using descriptive analysis Likert Scale. In the other hand, the quantitative data were used to give value to the indicators (or variables). M eanwhile, the proper analysis method to be applied in these data were paired sample t-test and Ordinary Least Square (OLS) model. Sample collection was conducted in this study by using purposive sampling method. This study was considered as a case study since the data collection was done by interviewing microbusiness owners in three subdistricts in Purworejo (Purwodadi, Kutoarjo, and Bruno). The business owners that acted as respondents in this study were them who receive murabahah financing from BMT Bina Masyarakat Purworejo. There were 828 customers of BMT Bina M asyarakat that received murabahah financing with the funding platform less than 10 million rupiahs, and 98 customers were chosen to be respondents of the study.

\section{Likert Scale}

This scale usually used for assessing the attitude, reaction or perception of someone or a group of people towards a phenomenon. The assessment is conducted by scoring each indicator to be further classified to the certain categories. The formula to classify each indicator into certain categories set out as follows:

Score $=$ number of respondents who has a certain answer $\times$ score of the category

Likert scale was used in this study to assess the respondents' perception towards the effectivity of financing that was conducted by BMT Bina 
Masyarakat Purworejo. The assessment was detailed to several aspects, they are the stage of financing proposal, the stage of financing disbursement, the stage of financing utilization, and the stage of financing payback. The total scores that were used in this study ranged from 294 to 882 . These values were obtained by multiplying the highest and lowest category's score with a total number of respondents and the number of aspects. The lowest category's score gave 294, while the highest gave 882.

Total Score $=$ sum score of each category

Classification of the effectiveness criteria was determined by the formula below: ${ }^{16}$

Percentage of Effectiveness $=\frac{\text { Total score of each category }}{882} \times 100 \%$

Based on the formula, effectiveness criteria of each aspects were:

1. $0 \%-25 \%=$ Do not effective

2. $26 \%-50 \%=$ Less effective

3. $51 \%-75 \%=$ Quite effective

4. $76 \%-100 \%=$ Effective

\section{Paired Sample ttest}

Paired sample t-test is an analysis procedure that has a capability in comparing the average of two paired or correlated sample. ${ }^{17}$ In this study, a t-test was used to compare the profit and income of the microbusiness before and after joining the BMT's financing program.

\section{O rdinary Least Square (OLS)}

OLS is a common technique in regression analysis, besides that, OLS is a method that is considered easy and covering many situations as long as the coefficient of the variables in the OLS model is considered BLUE (Best Linear Unbias Estimator). Multiple regression analysis is a regression that detects a correlation between the dependent variable and several other independent variables. ${ }^{18}$ M ultiple regression model was used in this study to analyze the effectiveness of islamic microfinance to alleviate the microbusiness owners' poverty before and after joining the financing program. The dependent variable of this study was the profit of business after joining the financing program and actually receiving the fund. The best model of the study set out as follows: 
$\operatorname{Ln} Y_{i}=b_{0}+b_{1} D E T K+b_{2} J A P+b_{3} D J U S+b_{4} \operatorname{LnJPY}+b_{5} \operatorname{LnPNG}$ $+b_{6} L U S+b_{7} P N D+e_{i}$

Keterangan:

$\operatorname{LnY} Y_{i}=$ Profit of the business after receiving murabahah fund (rupiah)

$\mathrm{b}_{\mathrm{o}}=$ Intercept

$b_{i}=$ Coefficient of the-i variable

DETK $=$ Dummy ethics and moral $(1=$ good ethics and moral, $0=$ bad ethics and moral)

JAP = Number of the financial provider in the family (people)

DJUS $=$ Dummy type of business $(1=$ trade, $2=$ service, $3=$ manufacture)

LnJPY = Financing/funding amount (rupiah)

LnPGN $=$ Household spending (rupiah)

LUS $=$ Age of business (year)

PND = Education (year)

$\mathrm{e}_{\mathrm{i}}=$ Error

\section{H eadcount Ratio Index (H)}

Headcount Ratio index was used in this study to measure the number of microbusiness owners in Purworejo that live under the poverty line as a percentage of total respondents. The category of poverty was based on the poverty line standard that was released by World Bank (US\$ 2 per capita per day or approximately 26000 rupiahs per capita per day).

$\mathrm{H}=\frac{\mathrm{q}}{\mathrm{n}}$

Note:

$\mathrm{H}=$ headcount ratio

$q=$ the number of business owner that lives under the poverty line

$\mathrm{n}=$ the number of observed sample

\section{Poverty G ap Index (P1) and the Income Gap Index (I)}

Poverty Gap Index (P1) and the Income Gap Index (I) was used to measure the intensity of poverty and often considered as representing the depth of poverty. The formulation is set out as follows: 
$P_{1}=\sum_{i=1}^{q} \frac{z-y_{i}}{q}$

Explanation:

$\mathrm{P}_{1} \quad=$ Poverty gap

$z \quad=$ Poverty line

$\mathrm{y}_{\mathrm{i}} \quad$ = Income of the-i business owner

$q=$ The number of microbusiness owners that live under the poverty line

$$
I=\sum_{i=\in S(z)} \frac{g_{i}}{q z}
$$

Explanation:

I = Income gap ratio

$g_{i}=$ difference between the poverty line and individual income

$\mathrm{q}=$ The number of microbusiness owners that live under the poverty line

$\mathrm{z}$ = Poverty line

\section{Sen Index of Poverty (P2)}

Sen Index of Poverty or poverty severity index was used in this study to explain the income gap between poor people.

$$
\begin{aligned}
& P 2=H[I+(1-I) G p] \\
& H=\text { Headcount ratio } \\
& I=\text { Income-gap ratio } \\
& \mathrm{Gp}=\text { Gini coefficient of the poor business owner }
\end{aligned}
$$

The value of the Gini index (IG) ranges between $0-1$

Gini index $(I G)=0$, indicated a perfect income equality

$0<\mathrm{IG}<0.3$, indicated a low income gap

$0.3 \mathrm{~d}$ "IG d" 0.5 , indicated a medium income gap

IG e" 0.5, indicated a high-income gap

\section{THE RESULT OF THE STUDY}

\section{Profile of BMT Bina Masyarakat Purworejo}

BMT Bina M asyarakat Purworejo was established in 1996 and was pioneered by a group of an islamic economic scholar in Purworejo. When it 
was first established, the capitalization was approximately 900000 rupiahs and was obtained from six of its pioneer. BMT Bina Masyarakat Purworejo is the first islamic financial institution in Purworejo. Up to this date, there have already been 6 BM Ts in Purworejo. BMT Bina M asyarakat Purworejo is a BMT that has the biggest asset of all the other islamic financial institutions in Purworejo. Its asset is more than 139.85 billion, its total business-owner-members are 47505 people, its total member that received its financing is 8850 people, and its human resource is 104 people. BMT Bina Masyarakat Purw orejo has 10 branches that spread out to many points in Purworejo. BMT Bina Masyarakat Purworejo gives an islamic microfinance service to many productive microbusinesses in Purworejo.

BMT Bina Masyarakat Purworejo also conducts social activities such as collecting and distributing zakat, infaq and sadaqah fund, along with cash waqf to be allocated in student scholarship, islamic da'wah, Aksi Cepat Tanggap (ACT) -a social organization-, Purworejo society's economic empowerment through BENMULYO business group, and sacrifice-animal distribution for poor people in Purworejo. All programs intend to alleviate the poverty.

Saving accounts that are provided by BM T Bina M asyarakat are wadiah, or namely SIRELA (simpanan suka rela lancar) -current account-, SimPelDawa (simpanan pelajar dan mahasiswa) -student saving-, SIAQUR (simpanan ahli qurban) -qurban (sacrifice) saving-, and hajj saving account namely multazam. While, mudharabah saving namely SISUKA (simpanan sukarela berjangka) - profit-sharing based contract-, with the profit-sharing rate for 25-45 percent. For the payment of the customers, BMT Bina Masyarakat Purworejo applied both direct payment in all of its office and 'jemput bola' system -Indonesian idiom which indicated the proactiveness of BMT's human resources on keeping in touch with the customers- This is one of the particular BMT's strategies to provide a wellperformed service for its customers, since most of its customers are trader that is busy with their business and have limited time to go to BMT's office. 


\section{Analysis on the Effectiveness of Islamic Microfinance in B MT Bina Masyarakat Purworejo}

The effectiveness of islamic microfinance is reflected in the funding procedure and its impact on the business. Funding procedure includes funding proposal, disbursement, and pay-back system. The impact includes the increase of income, profit, and business scale. ${ }^{19}$ In this study, the effectiveness of islamic microfinance in BMT Bina M asyarakat was assessed based on the customers' perception towards 4 aspects of BMT, they were financing proposal, disbursement, utilization, and pay-back by using a Likert Scale that already passed validity and reliability test.

\section{The effectiveness of Financing Proposal}

Financing proposal is the first step for the customer to access Islamic M Fl's financing. The indicators that were used in this study were financing eligibility, bureaucracy easiness, and collateral.

\section{Table 4 Customers' perception towards the effectiveness of financing} proposal in B MT B ina Masyarakat Purworejo

\begin{tabular}{llllll}
\hline \multirow{2}{*}{ No } & \multirow{2}{*}{ Indicator } & Score & \multicolumn{2}{c}{ Total } \\
\cline { 3 - 5 } & & $\mathbf{A ~ ( 3 )}$ & $\mathbf{B ~ ( 2 )}$ & $\mathbf{C ~ ( 1 )}$ & \\
\hline 1 & Financing eligibility & 98 & 0 & 0 & 294 \\
2 & Bureaucracy easiness & 98 & 0 & 0 & 294 \\
3 & Collateral & 97 & 1 & 0 & 293 \\
\hline Total & \multicolumn{5}{c}{881} \\
\hline \multicolumn{5}{c}{ Source: Primary data 2018 (processed) }
\end{tabular}

Explanation:

Score 3 for 'easy'

Score 2 for 'normal'

Score 1 for 'hard'

As demonstrated in table 4, 100 percent respondents stated that the eligibility to be a financing customer in BMT was considered easy to be fulfilled, In fact, all respondents had already been eligible for the financing program. All respondents also stated that the bureaucracy of the Islamic MFI was considered easy since 100 percent of respondents chose 'easy' as the rate of the bureaucracy. It was indicated that bureaucracy or procedure that is applied in Islamic M FI was easy to be met.

However, 98.98 percent of respondents stated that the collateral criteria were easy to be met. While the remaining 1.02 percent or equal as exactly one respondent stated that the collateral criteria of Islamic MFI 
were considered as normal in term of easiness. This indicated that Islamic M FI has maintained the considerably easy criteria of collateral that is needed to obtain financing since almost all of the respondents chose 'easy' as the rate of collateral criteria easiness. In this case, the criteria of the collateral in Islamic M Fl set out as follows:

1. Various property is able to be used as collateral, such as proof of motor vehicle ownership, proof of land ownership, household asset, or electronic devices these are all depending on the amount of the financing.

2. For the financing platform that is less than three million rupiahs, the collateral should be household assets or electronic devices.

3. For the financing platform that is less than one million rupiahs, Islamic $\mathrm{MFI}$ did not obligate the submission of collateral to the customer.

In the fatwa of DSN MUI No 4/DSN-MUI/IV/2000 regarding murabahah, it was clearly stated that collateral is permissible to be conducted to guarantee the sincerity of customer in joining murabahah contract. ${ }^{20}$ Total score of financing proposal effectiveness was 881 or 99.88 percent. The result indicated that the Islamic M Fl's system in the aspect of the financing proposal was considered effectively conducted.

Table 5 Customers' perception towards the effectiveness of financing disbursement in BMT Bina Masyarakat Purworejo

\begin{tabular}{|c|c|c|c|c|c|}
\hline \multirow{2}{*}{ No } & \multirow{2}{*}{ Indicator } & \multicolumn{3}{|c|}{ Score } & \multirow{2}{*}{ Total } \\
\hline & & $A(3)$ & B (2) & C (1) & \\
\hline 1 & $\begin{array}{l}\text { The time gap between acceptance and } \\
\text { actual disbursement }\end{array}$ & 94 & 4 & 0 & 290 \\
\hline 2 & Administration cost of disbursement & 90 & 8 & 0 & 286 \\
\hline 3 & $\begin{array}{l}\text { The capability of BMT to fulfill the } \\
\text { disbursement }\end{array}$ & 92 & 6 & 0 & 288 \\
\hline Tota & & & & & 864 \\
\hline
\end{tabular}

Source: Data primer 2018 (processed)

Explanation:

Score 3 for 'fast/affordable/match'

Score 2 for 'medium/medium/less match'

Score 1 for 'slow/unaffordable/unmatch'

\section{The effectiveness of Financing D isbursement}

The next step after the financing proposal is financing disbursement. Islamic MFI uses two system for the financing disbursement, first, the customer directly comes to the office, and second, the human resource of 
Islamic M Fl comes to the customer. In this study, the assessment of financing disbursement effectiveness was based on three indicators, they were a time gap between acceptance and actual disbursement, administration cost of disbursement, and the capability of Islamic M FI to fulfill the disbursement. The result is demonstrated in Table 5.

The total of 95.92 percent respondents stated that disbursement process was considered fast since the time gap between acceptance and the actual disbursement was not very long (less than 7 days on average). The remaining 4.08 percent stated that the process was considered medium in the speed (7 days to 1 month on average).

The administration cost of disbursement is charged through two ways. First, the cost is directly cut from disbursement amount and second, the cost is paid separately. The amount of administration cost varies for different customers depends on the financing platform. The total 91.84 percent of respondents stated that the cost was considered affordable and did not burden the customer. Meanwhile, the remaining 8.16 percent respondents stated that the cost was considered medium in the amount (affordability) and slightly burden the customer. The total 93.88 percent respondents stated that Islamic MFI had the capability to disburse the amount of financing as requested by the customer. Meanwhile, the remaining 6.12 percent respondents stated that Islamic M FI had less capability in disbursing the amount of financing as requested by the customer. This was happened due to the presence of many aspects that need to be considered by Islamic MFI in deciding the amount of financing for the customers, such as due diligence review, collateral, and financing model.

The total score for financing disbursement effectiveness was 864 or 97.95 percent. This result indicated that the financing disbursement in Islamic M FI was considered to be effective. However, the Islamic M FI need to maintain and increase its performance so that the financing is able to be used by the customer soon.

\section{The effectiveness of Financing $U$ tilization}

The assessment of financing utilization effectiveness in this study was done based on three aspects, they are control and assistance towards customer's business, Islamic M Fl's response in time of consulting, and the activeness of Islamic M Fl's human resource in giving advice for the development of customer's business. The result is shown in table 6 . 
Table 6 Customers' perception towards the effectiveness of financing utilization in BMT Bina M asyarakat Purworejo

\begin{tabular}{|c|c|c|c|c|c|}
\hline \multirow{2}{*}{ No } & \multirow[t]{2}{*}{ Indicator } & \multicolumn{3}{|c|}{ Score } & \multirow{2}{*}{ Tota } \\
\hline & & A (3) & $B(2)$ & $C(1)$ & \\
\hline 1 & $\begin{array}{l}\text { Control and assistance towards customer's } \\
\text { business }\end{array}$ & 90 & 8 & 0 & 286 \\
\hline 2 & BMT's response in time of consulting & 95 & 3 & 0 & 291 \\
\hline 3 & $\begin{array}{l}\text { Activeness of BMT's human resource in } \\
\text { giving advice for the development of } \\
\text { customer's business }\end{array}$ & 87 & 11 & 0 & 283 \\
\hline Tota & & & & & 860 \\
\hline
\end{tabular}

Source: Primary data 2018 (processed)

Explanation:

Score 3 for 'active/hospitable'

Score 2 for 'less active/normal'

Score 1 for 'inactive/inhospitable'

Table 6 shows that 91.84 percent respondents stated that Islamic M FI's human resources had actively controlled and assisted the development of customer's business. M eanwhile, the remaining 8.16 percent respondents stated that Islamic M FI's human resources less active in the control and assistance towards the development of customer's business. This was happened due to an imbalance between the number of financing customer and Islamic M FI's human resources so that the control and assistance were not able to be conducted with all of the customers.

The total 96.94 percent respondents stated that during consultancy, the Islamic M FI's human resources were considered hospitable. This is consistent with the actual case where the customer had already known the Islamic M Fl's human resources beforehand, even several of them were relatives or neighbor. While, the remaining 3.06 percent respondents stated that BM T's human resource showed a normal response during consultancy, neither hospitable nor inhospitable.

The total 88.78 percent of respondents stated that the Islamic MFI's human resources actively gave motivation and advice for the development of customer's business. Meanwhile, the remaining 11.22 percent respondents stated that they were less active in giving the motivation and advice for the development of the business.

The total score for financing utilization effectiveness was 860 or 97.50 percent. In conclusion, the financing utilization of Islamic M FI was considered effective. However, Islamic M FI needs to maintain and upgrade its performance to give a maximum service to the customer. 


\section{The effectiveness of Financing Pay-B ack}

In this study, the aspect of assessment regarding financing pay-back consisted of three aspects, they were the percentage of margin, the consistency of the customer in paying back the financing and its margin, and the length of financing pay-back period. The profit-sharing ratio was determined based on the agreement and the amount of financing. The margin ranged from 3 to 5 percent.

Table 7 Customers' perception towards the effectiveness of financing payback in BMT Bina Masyarakat Purworejo

\begin{tabular}{llllll}
\hline \multirow{2}{*}{ No } & \multirow{2}{*}{ Indicators } & Score & & \multirow{2}{*}{ Total } \\
\cline { 3 - 5 } & & $\mathrm{A}(3)$ & $\mathrm{B}(2)$ & $\mathrm{C}(1)$ & \\
\hline 1 & Margin percentage & 88 & 10 & 0 & 284 \\
2 & $\begin{array}{l}\text { The consistency of the customer in } \\
\text { paying back the financing and its margin }\end{array}$ & 50 & 35 & 13 & 233 \\
3 & $\begin{array}{l}\text { The length of pay-back period } \\
\text { Total }\end{array}$ & 90 & 8 & 0 & 286 \\
\hline
\end{tabular}

Explanation:

Source: Primary data 2018 (processed)

Score 3 for 'low/active/short'

Score 2 for 'medium/less active'

Score 1 for 'high/inactive/long'

As shown in table 7 , the total 89.80 percent of respondents stated that the margin percentage was considered low. The customer did not feel burdened by the margin that was determined by Islamic M FI. While, the remaining 10.20 percent respondents stated that the percentage of margin was medium, which means that the amount was still in the customer's capability even if it did not necessarily low.

The total 50.02 percent respondents stated that they had actively paidback the financing along with its margin. This was allowed due to the short distance between the customer's domicil and Islamic M FI's office, so they diligently paid it in the Islamic M Fl's office. The total 35.71 percent respondents stated that they were less active in paying-back the financing along with its margin. In several cases, the customers were not able to always deliver the payment to the office by themselves, and so the Islamic MFI's human resource sometimes need to pick it up in the customer's domicile. Meanwhile, the remaining 14.27 percent respondents stated that they were inactive in paying back the financing along with its margin and always need to be visited by the Islamic M FI's human 
resources to deliver the payment. In many cases, this was due to the long distance between the customer's domicile and Islamic M Fl's office.

The total 91.84 percent respondents stated that the pay-back period was considered short. This was happened due to the domination of customers that chose the short-term financing. Besides that, Islamic M FI also prioritized the short-term financing (less than 2 years) over the long-term financing. Meanwhile, the total 8.16 percent of respondents stated that the pay-back period was considered medium with the approved period range and margin percentage.

The total score for financing pay-back effectiveness was 803 or 91.04 percent. In conclusion, the Islamic M Fl's financing pay-back system was considered effective. However, the Islamic M Fl needs to continuously maintain and upgrade its system to give better service to the customer, especially regarding financing a pay-back system.

\section{The Impact of Microfinance on the Microbusiness Perfor- mance}

The analysis of the microfinance impact on the microbusiness performance that was proxied by profit was conducted using paired sample ttest. This paired sample t-test was done through assessing the difference of two types of profit (profit of the business before receiving Islamic M Fl's financing, and profit of the business after receiving Islamic M Fl's financing). The data need to pass normality test before being tested using paired sample t-test. The normality test was conducted by using KolmogorovSmirnov table. The probability value was more than 5 percent and the data was considered to pass the normality test.

Table 8 The result of paired sample ttest

\begin{tabular}{llllll}
\hline & Mean & Std Deviation & Std Error Mean & $\mathbf{t}$ & Sig \\
\hline $\begin{array}{l}\text { Profit } \\
\text { difference }\end{array}$ & $-2.025 \mathrm{E} 6$ & 1524161.062 & 153963.517 & -13.151 & 0.0000 \\
\hline
\end{tabular}

Source: Primary data 2018 (processed)

Table 8 shows that there was a difference between the two types of profit. The profit before financing minus the profit after financing was 2.025E6. The negative sign indicated that the profit after financing was higher than the profit before financing. The t-test demonstrated a significant result as shown in the significance level that was $0.000<$ alpha 5 
percent. In conclusion, the average profit before financing and after financing was statistically different.

The result also indicated that the financing that was given by Islamic M FI had a positive and significant effect on the development of customer's microbusiness. This result was consistent with the customers' perception which stated that there was an increase in their business profit. The increase of business profit directly led to the increase of business scale. The increase of the profit was experienced after Islamic M Fl's financing that was received by business owner. This was allowed to be achieved due to the utilization of the financing was indeed for the business matter instead of a private owner's consumption.

The paired sample t-test result indicated that islamic microfinancing that was given by Islamic M FI had a positive effect on the business profit of the Islamic M Fl's customers. In addition and as an insight, further analysis regarding the impact of islamic microfinance on the development of micro business was conducted using Ordinary Least Square (OLS). The estimation result of multiple regression that was obtained from OLS method was tested using Eviews 9. Before conducting the estimation, the data were treated by multiple tests for attaining BLUE (Best Linear Unbiased Estimator) model. For this regards, the model needs to be acquired from autocorrelation, multicollinearity, and heteroscedasticity. Moreover, the model also need to meet the assumption in f-test and t-test. However, before these all, the model need to pass the normality test.

The normality test was conducted and the result showed that the obtained probability value was 0.4647 , that means, the probability value $>$ 5 percent significance level. in conclusion, the error of the model was normally distributed and the normality assumption was fulfilled by the model.

The heteroscedasticity test was conducted to detect the presence of heteroscedasticity issue in the model. The test was conducted using the White test. The white test result showed that the probability value that was obtained was $0.465>5$ percent significance level. In conclusion, the model was not contravened the assumption regarding heteroscedasticity.

The autocorrelation test was conducted to detect the presence of autocorrelation issue in the model. The test was conducted using the Breusch-Godfrey Serial Correlation LM Test. The result of the test showed that the probability F-statistic value was 0.14177 , and it was less than 5 
percent significance level. That means the model was acquired from autocorrelation issue.

Multicollinearity test was conducted to detect the presence of multicollinearity issue in the model. The test was conducted using Variance Inflation Factors (VIF) value of every variable in the model. The value that was less than 5 percent indicated that the model was acquired from multicollinearity issue.

The value of probability F-statistic was 0.000 . Probability F-statistic value that was less than 5 percent significance level indicated that the independent variables in the model (Dummy ethics and moral, Number of breadwinner in the family, Dummy type of business, Financing/funding amount, Household spending, Age of business, and Education) altogether had significantly affected the increase of business profit in the 5 percent significance level.

The R-Squared value of the equation was 71.9 percent, that means, the 71.9 percent of dependent variable's variance was able to be explained by the model, while the remaining 28.1 percent was explained by the factors that were not included in the model.

The variable of dummy ethics and moral's coefficient was positive $(0.021944)$ and the probability value was 0.0174 (less than 5 percent significance value). That means the variable of dummy ethics and moral had a positive and significant effect on the business profit in the 5 percent significance level. The result was consistent with the study which stated that ethics and moral had a positive and significant effect on the microbusiness profit rate. ${ }^{21}$ The islamic financing scheme that contains ethics and moral attribute motivates the business owner to develop their business. $^{22}$

The variable of the breadwinner number of the family had a positive and significant effect on the 10 percent significance level. The coefficient value of the variable was 0.049090 . this result was consistent with the study which stated that the breadwinner number of the family had a positive effect on the family's income. ${ }^{23}$

Variable of Dummy type of business had a positive and significant effect on the business profit in the 1 percent significant level. the variable's coefficient was 0.155198 . That means trade business had the bigger profit than the other business type (approximately 0.155198 percent times). Dummy type of business had a positive and significant effect on the 
microbusiness income. ${ }^{24}$ This result was consistent with the study which stated that the type of business had a positive and significant effect on the business profit increase. ${ }^{25}$

Table 9 The Result of 0 rdinary Least Square (OLS) model

\begin{tabular}{lll}
\hline \multirow{2}{*}{ Variable } & Result & \\
\cline { 2 - 3 } & Coefficient & Prob \\
\hline C & 11.91262 & 0.0000 \\
Dummy ethics dan moral & 0.021944 & $0.0174^{* *}$ \\
Number of financial provider in the family & 0.049090 & $0.0649^{*}$ \\
Dummy type of business & 0.155198 & $0.0034^{* * *}$ \\
(Natural Logarithm) The amount of financing & 0.184226 & $0.0358^{* *}$ \\
(Natural Logarithm) Household spending & -0.141652 & $0.0230^{* *}$ \\
Age of business & 0.046810 & $0.0000^{* * *}$ \\
Education & 0.160920 & $0.0023^{* * *}$ \\
\hline R-squared & 0.719507 & \\
Adjusted R-squared & 0.697691 & \\
Prob (F-statistic) & 0.000000 & \\
\hline
\end{tabular}

Source: Primary data 2018 (processed)

Explanation: *) significant on 10 percent significance level

**) significant on 5 percent significance level

***) significant on 1 percent significance level

Variable of financing amount had a positive and significant effect on the business profit on 5 percent significant level. The coefficient value was 0.184226 . This was consistent with the study which said that the presence of credit or financing in a microbusiness led to the increase of the microbusiness income. ${ }^{26}$ The amount of financing had a positive and significant effect on the development of microbusiness. ${ }^{27}$

Variable of household spending had a negative and significant effect on the 5 percent significance level. The coefficient was -0.141652 . That means, the increase in household spending by 1 percent, eventually led to the decrease of business profit by 0.141652 percent, ceteris paribus. This was consistent with the study which stated that the average spending had a significant effect on the business development. ${ }^{28}$ In the actual case, the spending of a business owner's household was for both private consumption and business capital.

Variable of the age of business had a positive and significant effect on the 1 percent significant level. The coefficient of the variable was 0.046810 . 
That means, the increase of microbusiness age by 1 percent eventually led to the increase of microbusiness profit by 0.046810 percent. The result was consistent with the finding of the previous study which stated that the age of microbusiness affected the development of the microbusiness. ${ }^{29}$ Microbusiness income was affected in a positive direction by the age of business. ${ }^{30}$ In the actual case, the business owner who had already in the business for years tend to attain more business partners and a more loyal customer. These factors led to the increase of business profit.

Variable of education had a positive and significant effect on the 1 percent significance level. The result indicated that the higher the education of the business owner, the higher the business profit was. The coefficient of the variable was 0.160920 . That means, the increase of microbusiness owner's education by one percent eventually led to the increase of business profit by 0.160920 percent. This result was consistent with the study which stated that the education level of the owner had a positive and significant effect on the development of microbusiness. ${ }^{31}$ In the actual case, the business owner that possess a higher education level tend to be more active in managing the business. One of the management strategies that was applied was the utilization of social media for product marketing and business partner networking. These factors led to the increase of business profit.

\section{The Impact of Islamic Microfinance on the Microbusiness O wner's Poverty Alleviation}

In this study, the analysis regarding the impact of islamic microfinance on micro business owner's poverty alleviation was conducted by an assessing the difference between microbusiness owner's income before and after joining Islamic M FI's financing program. Numerous studies had already explained the impact of islamic microfinance on the poverty alleviation by analyzing the increase in customer's income. Besides the assessment of income difference using paired sample t-test, this study also conducted the comparison of poverty level by using several poverty indicators, they were headcount ratio, poverty gap index, income gap index, and sen index of poverty.

Regarding the business owner's income increase, the total 80 respondents or 81.63 percent of total respondents stated that they had experi- 
enced the increase in income. M eanwhile, the remaining 18 respondents or 18.37 percent of respondents stated that their income was considered constant without any increase or decrease. Paired sample t-test was conducted to assess the difference between microbusiness owner's profit before Islamic microfinancing and microbusiness owner's profit after islamic microfinancing.

Table 10 The result of paired samplettest

\begin{tabular}{llllll}
\hline & Mean & Std Deviation & $\begin{array}{l}\text { Std Error } \\
\text { Mean }\end{array}$ & t & Sig \\
\hline Income difference & $-1.006 \mathrm{E} 6$ & 1991691.706 & 201191.244 & -5.002 & 0.000 \\
\hline \multicolumn{5}{c}{ Source: Primary data 2018 (processed) } \\
\end{tabular}

The microbusiness owner's income difference before and after financing was -1.006E6. Besides that, the value of sig (two-tailed test) 0.000 and less than $(<) 5$ percent significance value. The results indicated that statistically, there was a significant difference between a microbusiness owner's income before and after financing. In conclusion, Islamic M Fl's financing had a positive and significant effect on the business owner's income increase. This result was consistent with the study which stated that the financing of Islamic MFI had a positive and significant effect on the income increase of their financing customer. ${ }^{32}$

Table 11 Indicators of poverty before and after financing

\begin{tabular}{lll}
\hline Indicator of poverty & Before financing & After Financing \\
\hline H & 0.153 & 0.122 \\
P1 (Rupiah) & 500900 & 498069.4 \\
I & 0.591 & 0.326 \\
P2 & 0.308 & 0.306 \\
Gp & 0.109 & 0.065 \\
\hline
\end{tabular}

Source: Primary data 2018 (processed)

As shown in table 11, the value of Headcount ratio before financing was 0.153 . It means the total of 0.153 percent of respondents was considered poor based on the World Bank's poverty line. After obtaining Islamic M Fl's financing, the value of Headcount ratio decreased to be 0.122 . In conclusion, the Islamic MFI had an ability to reduce the number of micro business owners that live under the poverty line.

The value of the poverty gap index (P1) experienced a decrease from 500900 rupiahs to 498069.4 rupiahs. It means, the average gap between the poor business owner and poverty line that was 500900 rupi- 
ahs had decreased to 498069.4 rupiahs with the Islamic M FI's financing. Income gap index (I) also experienced a decrease from 0.591 to 0.326 after business owners received the financing from Islamic $\mathrm{M} \mathrm{FI}$.

The value poverty severity index or sen index (P2) also showed a decrease from 0.308 to 0.306 after business owners received Islamic M FI's financing. On the other hand, analysis of Gini coefficient of the poor (Gp) was used to detect the sign of income gap between microbusiness owners, before and after financing. The $\mathrm{Gp}$ value of microbusiness owners before financing was 0.109 , and after financing was decreased to 0.065 . It indicated that the income gap between microbusiness owners was considered low before financing and even became lower after financing.

The decrease of these poverty indexes was caused by the increase of microbusiness income. The additional income that was obtained was indicated to be the result of Islamic M FI's financing to the microbusiness. In fact, the Islamic M Fl's financing of microbusiness was properly used by microbusiness owners to further develop the business.

Based on the results above, the general conclusion was able to be stated. The Islamic M Fl's financing had a positive and significant effect on the microbusiness owners' poverty alleviation. This result was consistent with the finding which stated that islamic microfinance had a positive and significant impact in the two different area. ${ }^{33}$ This was also supported by the finding which stated that Islamic M FI's financing had an impact on the poverty alleviation in three different area's typology. ${ }^{34}$

\section{CONCLUSION}

Based on the results of the study, the conclusions that were obtained set as follows:

1. The islamic microfinancing distribution that was managed by Islamic MFI was considered to be effective for the aspect of financing proposal, financing disbursement financing utilization and financing payback.

2. Islamic micro-financing had a positive impact on the performance of microbusiness. This was indicated by the increase of microbusiness profit after the owner joined the Islamic M Fl's financing program.

3. Islamic MFI's financing had a positive and significant effect on microbusiness owners' poverty alleviation. This was reflected in the increase of microbusiness owners' income. 


\section{RECOMMENDATION}

1. Islamic MFls are encouraged to maintain and upgrade their performance to increase the effectiveness of their financing program and make it works on its maximum capability since there is more potential to be managed.

2. The Islamic M Fl's financing to broaden its outreach, since the result of the study showed that islamic micro-financing had a positive impact on microbusiness owners' poverty alleviation.

3. The next studies regarding this topics are expected to broaden the area coverage and to consider a comparison between areas. Besides that, the other poverty indicators are also able to be used, for example, the world poverty line.

\section{ENDNOTES}

1 "Angka Kemiskinan", BPS, akses 09 Mei 2017, http//bps.go.id/ angka_kemiskinan.

2 Hadim, "Dinamika Kemiskinan Rumah Tangga di Pedesaan (Studi Kasus Malasari, Kecamatan Nanggung, Kabupaten Bogor, Provinsi Jawa Barat", (Skripsi Institut Pertanian Bogor, 2009).

3 Muhammad, Lembaga Keuangan Mikro Syari'ah (Yogyakarta: Graha IImu,2009).

4 "Perkembangan Data U saha Mikro, Kecil, dan Menengah (U M KM), dan U saha Besar", Kementerian Koperasi dan U M KM , H ard copy, dicopy 2018 Mei 03.

5 Mufida Amalia Azzahra, "Analisi Faktor-Faktor yang Mempengaruhi Permintaan Pembiayaan Mudharabah bagi UMKM dan Efektivitas Pembiayaan M udharabah bagi U M KM (Studi Kasus: BM T X Jakarta)", (Skripsi Institut Pertanian Bogor, 2004).

6 "Peraturan Bank Indonesia No. 15/ 12/ PBI/ 2013 Tanggal 12 Desember 2013 tentang Kewajiban Penyedian M odal M inimum Bank U mum", Bank Indonesia, akses 2018 Mei 09, http//bi.go.id/ peraturan_bank_indonesia_no_15_tahun 2013.

7 Syukur, "Analisis Keberlanjutan dan Perilaku Ekonomi Peserta Skim Kredit Rumah Tangga Miskin", 2002.

8 Indah Purnamasari, "Analisis Efektivitas dan Faktor-Faktor Pengembalian Pembiayaan U saha M ikro dan Kecil pada Lembaga Keuangan Mikro Syariah (Studi Kasus: Korpin Jasa Syariah Pekalongan)", (Skripsi Institut Pertanian Bogor, 2011).

9 Noruwa Al, Emeka EJ, "The Role and Sustainability of M icrofinance Banks in Reducing Poverty and D evelopment of Enterpreunership in $U$ rban and Rural A reas in N igeria", International Journal of Business Administration 3, 
No 3, (2012).

10 Ledgerwood, Joanna, "M icrofinance H andbook: An Institutional and Financial Perspective (Sustainable Banking with The Poor)", (Wangshiton DC: The World Bank, 1999).

11 R madhian, "A nalisis Faktor-Faktor yang M empengaruhi Jangkauan Pembiayaan M ikro: Studi Kasus BT PN Syariah", (Skripsi Institut Pertanian Bogor, 2015).

12 Beik IS, Arsyianti LD, "Ekonomi Pembangunan Syariah", (Bogor: IPB Press, 2016).

13 Zeller M, M eyer RL, "The Triangle of M icrofinance: Financial Sustainability, O utreach, and Impact", (London (G B): The Johns H opkins U niversity Pr, 2002).

14 Mustica Bintang Sabiti, "Efektivitas Pembiayaan Mikro Syariah dan Dampaknya terhadap Pengurangan Kemiskinan di Kabupaten Bogor (Studi Komparatif Desa Swasembada dan Desa Swakarya)", (Skripsi Institiut Pertanian Bogor, 2016).

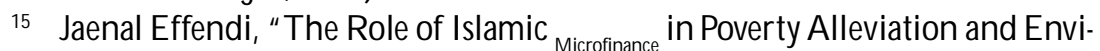
ronmental Awareness in Pasuruan East Java Indonesia", (D isertasi U niverstatdrucke G ottingen, 2013).

16 Riduwan Akdon, "Rumus dan Data dalam A nalisis Statistika", (Bandung: Alfabeta, 2009).

17 Wahyono, "25 M odel Analisis Statistik dengan SPSS 17: M emahami Teknik Analisis Statistik Secara Sistematis dan Praktis", (Salatiga: Pt Elex M edia Komputindo, 2009).

18 M Firdaus, et al. "A plikasi M etode Kuantitatif untuk M anajemen dan Bisnis", (Bogor: IPB Press, 2011).

19 A ryati, "Analisis Permintaan dan Efektivitas Pembiayaan U saha Kecil pada Lembaga Keuangan M ikro Syariah (Studi KasusK BM T Khidmatul U mmah", (Skripsi Institut Pertanian Bogor, 2006).

20 "M urabahah", D ewan Syariah N asional M ajelis U lama Indonesia, akses 2017 M aret 09, http:/ / dsnmui.or.id/ produk/ fatwa.

${ }^{21}$ Neva Sunba Dena, "Analisis Pengaruh Pembiayaan Murabahah terhadap Perkembangan U saha M ikro di BM T Insan M ulia Kota Palembang", (Skripsi Institut Pertanian Bogor, 2015).

22 Rahman, Abdul Rahim Abdul, "Islamic Microfinance: An Alternative to Poverty Allevation", International Journal of I slamic and M iddle Eastern Finance and $M$ anagemen (26) 2010.

23 W idya Gina, Jaenal Effendi, "Financing Program in Microfinance Institut (LKMS) of Welfare Enhancing for M icro Business Enterprices (C ase Study in BMT Baitul Karim Bekasi", Jurnal AI M uzara'ah (3), No. 1, 2015.

24 Siti Karimah, "D ampak Pebiayaan Q ordhul H asan terhadap Perkembangan U saha Mikro (Studi Kasus BMT AI Husnayain Jakarta", (Skripsi Institut Pertanian Bogor, 2015).

25 Cyntia Putri Prameswari, "A nalisis Struktur Permodalan U saha Mikro dan 
Kecil (U MK) dan Kaitannya dengan Perkembangan U saha di Kabupaten Bogor", (Skripsi Institut Pertanian Bogor, 2014).

26 Johana Elvira Putri, " Analisis Profil dan Pemanfaatan Kredit O leh U saha M ikro serta D ampaknya pada Perkembangan U saha (Kasus D esa Pabuaran, Kecamatan Cibinong, K abupaten Bogor)", (Skripsi Institut Pertanian Bogor, 2013).

27 Neva Sunba Dena, "Analisis Pengaruh Pembiayaan Murabahah terhadap Perkembangan U saha M ikro di BM T Insan M ulia Kota Palemban g", (Skripsi Institut Pertanian Bogor, 2015).

28 W idya Gina, Jaenal Effendi, "Financing Program in Microfinance Institut (LKMS) of Welfare Enhancing for M icro Business Enterprices (C ase Study in BMT Baitul Karim Bekasi", Jurnal AI Muzara'ah (3), N o. 1, 2015.

29 M ursalina, "Dampak Zakat Produktif terhadap Perkembangan U saha M ikro Mustahik: Kasus pada U saha Mikro Binaan Baznas di Kabupaten Bogor", (Skripsi Institut Pertanian Bogor, 2015).

30 Ramuna, "Pengaruh Dana Zakat Produktif, Karakteristik U saha, dan Karakteristik D emografisterhadap Perkembangan U saha M ikro (Studi Kasus LAZ D PU D aarut Tauhiid Bogor), (Skripsi Institut Pertanian Bogor, 2016).

31 Luthfi Hibaur Rachman, "Dampak Pembiayaan Syariah terhadap Profitabilitas U saha M ikro pada Nasabah Bank Perkreditan Rakyat Syariah H arta Insan Karimah Kecamatan Ciledug Kota Tangerang", (Skripsi Institut Pertanian Bogor, 2014).

32 N ouva Paramitha, " A nalisis D ampak Pembiayaan M ikro Syariah terhadap Pendapatan dan Keuntungan U saha Anggota (Studi Kasus Koperasi Ikhtiar C abang D ramaga)", (Skripsi Institut Pertanian Bogor, 2017).

33 Mustica Bintang Sabiti, "Efektivitas Pembiayaan Mikro Syariah dan D ampaknya terhadap Pengurangan Kemiskinan di Kabupaten Bogor (Studi Komparatif Desa Swasembada dan Desa Swakarya)", (Skripsi Institiut Pertanian Bogor, 2016).

34 Jaenal Effendi, "The Role of I slamic M icrofinance in Poverty Alleviationand Environmental Awareness in Pasuruan East Java Indonesia", (Disertasi U niverstatdrucke G ottingen, 2013).

\section{BLIBLIOGRAPHY}

A kdon, Riduwan. 2009. Rumus dan D ata dalam A nalisis Statistika. Bandung (ID ): Alfabeta.

A zzahrah, M ufida A malia. 2014.A nalisisFaktorFaktor yang M empengaruhi Permintaan Pembiayaan M udharabah bagi U M K M dan Efektifitas Pembiayaan M udharabah bagi U M KM (Studi Kasus: BM T X Jakarta). [Skripsi]. Bogor (ID): Institut Pertanian Bogor.

Beik IS, Arsyianti LD. 2016. Ekonomi Pembangunan Syariah. Bogor (ID): IPB Press.

[BPS] Badan Pusat Statistik. Angka K emiskian. [Internet]. [diunduh 2017 Maret 09]. Tersedia pada: bps.go.id. 
Dena, Neva Sunba. 2015. Analisis Pengaruh Pembiayaan M urabahah terhadap Perkembangan U saha M ikro di BM T Insan M ulia K ota Palembang. [Skripsi]. Bogor (ID): Institut Pertanian Bogor.

[DSN -M U I] D ewan Syariah Nasional M ajelis U lama Indonesia nomor 4/ DSN MU I/IV/ 2000 tentang M urabahah. [Internet]. [diunduh 2017 Maret 09]. Tersedia pada: dsnmui.or.id/ produk/ fatwa.

Effendi J. 2013. "The Role of I slamic M icrofinance in Poverty A lleviation and Environmental Awareness in Pasuruan East Java Indonesia". Ph.D Dissertation, U niverstatdrucke Gottingen.

Firdaus M , H armini, Farid. 2011. A plikasi M etode K uantitatif untuk M anajemen dan Bisnis. Bogor (ID): IPB Press.

Gina, Widya dan Jaenal Effendi. 2015. Financing Program in M icrofinance Institut (LKMS) of Welfare Enhancing for M icro Business Enterprices (Study C ase in BMT Baitul Karim Bekasi). Journal A I-M uzara'ah. Vol 3. N o. 1.

H adim. 2009. Dinamika Kemiskinan Rumah Tangga di Pedesaan (Studi Kasus Malasari, Kecamatan Nanggung, Kabupaten Bogor, Provinsi Jawa Barat. [Skripsi]. Bogor (ID): Institut Pertanian Bogor.

Karimah, Siti. 2015. D ampak Pembiayaan Q ardhul Hasan terhadap Perkembangan U saha M ikro (Studi K asus BM T AL H usnayain Jakarta). [Skripsi]. Bogor (ID): Institut Pertanian Bogor.

[KEM EN KO P] Kementerian Koperasi dan U M KM . 2018. Perkembangan Data U saha M ikro, Kecil, dan M enengah (U M KM ), dan U saha Besar Tahun 20162017 [H ard C opy]. [dicopy 2018 M ei 14]. Tersedia dari Kementerian Koperasi dan U MKM.

M uhammad. 2009. Lembaga K euangan M ikro Syaria'ah. Yogyakarta (ID): G raha IImu.

M ursalina. 2015. D ampak Zakat Produktif terhadap Perkembangan U saha M ikro Mustahik: Kasus pada U saha Mikro Binaan Baznas di Kabupaten Bogor. [Skripsi]. Bogor (ID): Institut Pertanian Bogor.

Noruwa AI, EmekaEJ. 2012. The Role and Sustainability of M icrofinance Banks in Reducing Poverty and Development of Entrepreneurship in U rban and Rural A reas in N igeria. International Journal of B usiness A dministration. Vol. 3, No. 3.

[0]K] O toritas Jasa Keuangan. 2012. Peraturan Bank Indonesia Nomor 15/ 12/ PBI/ 2013 pengganti Peraturan Bank Indonesia 14/ 22/ PBI/ 2012 [Internet diunduh 2018 M ei 20]. Tersedia pada: https:/ / www.ojk.go.id/ id/ regulasi/ D ocuments/ Pages/ PBI tentang-Kewaji ban Penyediaan-M odal-M inimum-BankU mum-2013/ 1.pdf

Paramitha, Nouva. 2017. Analisis D ampak Pembiayaan M ikro Syariah terhadap Pendapatan dan Keuntungan U saha Anggota (Studi Kasus Koperasi Baytul Ikhtiar C abang D ramaga). [Skripsi]. Bogor (ID): Institut Pertanian Bogor.

Prameswari, C yntia Putri. 2014. Analisis Struktur Permodalan U saha M ikro dan Kecil (U MK) dan Kaitannya dengan Perkembangan U saha di Kabupaten Bogor. [Skripsi]. Bogor (ID): Institut Pertanian Bogor. 
Putri, Johana Elvira. 2013. Anal isis Profil dan Pemanfaatan Kredit O leh U saha M ikro serta D ampaknya pada Perkembangan U saha (Kasus D esa Pabuaran, Kecamatan Cibinong, Kabupaten Bogor). [skripsi]. Bogor (ID): Institut Pertanian Bogor.

Rachman, Luthfi Hibaur. 2014. Dampak Pembiayaan Syariah terhadap Profitabilitas U saha M ikro pada N asabah Bank Perkreditan Rakyat Syariah $\mathrm{H}$ arta Insan Karimah Kecamatan Ciledug Kota Tangerang. [Skripsi]. Bogor (ID): Institut Pertanian Bogor.

Rahman, A bdul Rahim Abdul. 2010. Islamic Microfinance: An Alternative to Poverty A llevation. International Journal of Islamic and M iddle Eastern Finance and $M$ anagemen. Vol 26.

Ramadhian. 2015. Analisis Faktor-Faktor yang M empengaruhi Jangkauan Pembiayaan Mikro: Studi Kasus BTPN Syariah. [Skripsi]. Bogor (ID ): Institut Pertanian Bogor.

Ramuna. 2016. Pengaruh Dana Zakat Produktif, Karakteristik U saha, dan K arakteristik D emografis terhadap Perkembangan U saha M ikro (Studi Kasus LAZ D PU Daarut Tauhiid Bogor). [Skripsi]. Bogor (ID); Institut Pertanian Bogor.

Sabiti, M ustica Bintang. 2016. Efektifitas Pembiayaan Mikro Syariah dan Dampaknya terhadap Pengurangan Kemiskinan di Kabupaten Bogor (Studi Komparatif desa Swasembada dan desa Swakarya). [Skripsi]. Bogor (ID): Institut Pertanian Bogor.

Syukur M. 2002. A nalisis K eberlanjutan dan Perilaku Ekonomi Peserta Skim K redit Rumah Tangga M iskin.

Wahyono. 2009. 25 M odel Analisis Statistik dengan SPSS 17: M emahami Teknik A nalisis Statistik secara Sistematis dan Praktis. Salatiga(ID): PT Elex Media Komputindo.

Zeller M, M eyer RL. 2002. The Triangle of M icrofinance: Financial Sustainability, $\mathrm{O}$ utreach, and Impact. London (G B): The Johns H opkins U niversity Pr. 